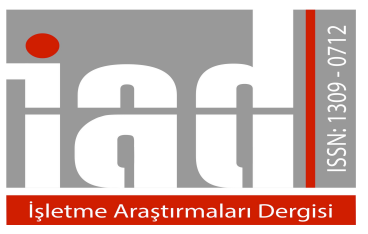

Journal Of

Business Research

Turk

www.isarder.org

\title{
A Comparison to National and Local Retailers With Respect to Service Quality Dimensions
}

\author{
Yusuf ARSLAN \\ Sakarya University \\ Faculty of Management \\ Sakarya, Turkey \\ yusufarslan@sakarya.edu.tr
}

\author{
Emre YILDIRIM \\ Sakarya University \\ Faculty of Management \\ Sakarya, Turkey \\ emreyildirim@sakarya.edu.tr
}

\begin{abstract}
The purpose of the study is to assess the consumers' perceived service quality levels towards national and local retailers. To reach this aim, four main hypotheses were tested. A questionnaire was formed to collect the data needed to test the hypotheses. The questionnaire was carried out to the 211 consumers who have shopped both from local and national FMCG (Fast Moving Consumer Goods) selling retailers. Convenience sampling methods was used in the study, picking voluntary costumers from either kind of retailers. The results indicate that, perceived service quality levels for national and local retailers are significantly different for Physical Aspects and Problem Solving dimensions. The results for Customer Interest and Personal Interaction dimensions were insignificant. Thus, according to the results, two hypotheses of the study were supported while two of them rejected.
\end{abstract}

Keywords: SERVQUAL, Retailing, FMCG

\section{Introduction}

The retail environment is changing more rapidly than ever before. It is characterized by intensifying competition from both domestic and foreign companies, a spate of mergers and acquisitions, and more sophisticated and demanding customers who have greater expectations related to their consumption experiences (Dabholkar et al. 1995, p. 3).

Retailing is changing rapidly also in Turkey. Turkish retail sector has been one of the most appealing sectors for both investors and consumers. Per capita disposable income grew $9 \%$ over the past 5 years and reached US\$8,895 in 2013; it is expected to exceed US $\$ 13,000$ in 2018. The total size of the retail sector in Turkey is estimated to have reached US\$303 billion in 2013 and is expected to grow 7\% between 2014 and 2018 (Deloitte Retail Sector Update, 2014, p. 3)

Considering the rapid growth and changing environment in Turkish retailing sector we can say that competition between retailing firms have reached at the highest level so far. Retailing companies are constantly trying new strategies to survive in this 
highly tough environment. Customer service has become one of the most important issues for the retailing companies to keep their customer satisfied. Service quality is increasingly being offered as a strategy by marketers to position themselves more effectively in the marketplace (Parasuman et al., 1988, p. 15) Thus, it can be said that, service quality has become one of the very important issues for the Turkish retailing sector.

The most widely known and discussed scale for measuring service quality is SERVQUAL, a scale designed to measure five dimensions of service quality: tangibles, reliability, responsiveness, assurance, and empathy. Although SERVQUAL has been empirically tested in a number of studies involving "pure" service settings (e.g., banking, long-distance telephone service, securities brokerage, and credit card service), it has not been successfully adapted to and validated in a retail store environment.(Dabholkar et al., 1995, p. 3)

Consumer service has been neglected especially for the fast moving consumer goods (FMCG) retail sector in Turkey as almost all the other countries. But nowadays it is highly noticed by almost every company who operates at the FMCG sector. Still it can be said that, there is a lack of studies measuring service quality with respect to FMCG sector.

\section{Turkish FMCG Sector}

The retail sector for FMCGs in Turkey is in the process of a drastic transformation. New, "modern" retail formats, like chain stores and hyper/supermarkets, have rapidly diffused in almost all major urban areas, and increased their market share at the expense of traditional formats (grocery shops, green groceries, etc.) in the last couple of decades. This rapid transformation has raised concerns about competitive conditions in the sector (Çelen et al., 2005, p. 1).

Turkey is ahead of all EU countries in Q2 2013 in terms of growth of the fastmoving consumer goods market - revealed Nielsen. The country's FMCG industry clocked $+11.6 \%$ year-on-year sales-growths in the second quarter. The aggregated sales growth of the FMCG sector in EU (including 21 countries) stood at a meagre $+1.2 \%$ year-on-year, compared to $+3.3 \%$ in Q1 2013. The low year-on-year growth in EU is owed to the negative sales growth rate in most of the countries (cmtevents.com).

During the 1990s, large retailers like Metro \& Carrefour entered Turkish market, stimulating extension of domestic chains as to defend local turf. Share of bakkal outlets dropped from $91,6 \%$ in 1996 to $82,8 \%$ in 2008. Yet, turnover market share of bakkals is $33 \%$, with cumulative market share of supermarket formats at $45,7 \%$ (BIM constituting 6,3\%). However the picture changes drastically when tobacco product turnover is taken out: total share of markets is $65,4 \%$, with BIM share $10,9 \%$ ( Küçükosmanoğlu et al., 2011, p. 8).

Discount-stores have shown the biggest growth after 2004 in Turkish FMCG sector having $23 \%$ of all Turkish retail trading volume. Bim, ŞOK and DiaSa are the biggest brands of discount stores in this channel. In 2008 A-101 has entered the market and has reached 580 stores in two years (Rekabet Kurumu, 2011: 14). Besides, some local retailers have shown great success stories at the cities they operate. Supermarkets, chains stores and foreign firms are likely to increase their market shares in the future. Any single retailer may not seem to establish a dominant position in the national market. However, the relevant markets in the retail sector should be defined locally 
rather than nationally. It is possible that some retailers may establish a dominant position in certain local markets, especially following a merger activity and/or exits (Çelen et al., 2005, p. 33).

FMCG retailers sell almost identical products. Therefore, price-competition is likely to be very important. If they have local market power, they would be able to raise their prices. Price comparisons could be helpful in identifying if some retailers (mostly, chain stores) enjoy a certain degree of market power. However, it is notoriously difficult to make a price comparison across retailers and/or retail type because each retailer sells a different basket of products and the number of products sold is very large (Çelen et al., 2005, p. 1). Therefore it can be said that, raising service quality can make a difference between all other stores and be able to make consumer to choose your store.

\section{Perceived Service Quality}

Service quality is a measure of how well the service level delivered matches customer expectations. Delivering quality service means conforming to customers' expectations on a consistent basis (Baron and Harris,2003, p. 137). Unlike goods quality, which can be measured objectively by such indicators as durability and number of defects, service quality is an abstract and elusive construct because of three features unique to services: intangibility, heterogeneity and inseparability of production and consumption (Parasuman et al., 1988, p. 13). Parasuman et al. (1985) suggested three underlying themes about service quality. By underlying these items they summed up studies carried out before their studies.

- Service quality is more difficult for the consumer to evaluate than goods quality.

- Service quality perceptions result from a comparison of consumer expectations with actual service performance.

- Quality evaluations are not made solely on the outcome of a service; they also involve evaluations of the process of service delivery.

Service quality is viewed as a multi-dimensional concept. Consumers assess and evaluate a number of factors or dimensions. SERVQUAL is a self-administered questionnaire purported to be a generic measure of service quality. In other words, it was designed to be applicable to a wide variety of services. The dimensions to be measured in the scale are (Mudie and Pirrie, 2006, pp. 92-93):

Reliability - the ability to perform the promised service dependably and accurately. It is regarded as the most important determinant of perceptions of service quality. This dimension is particularly crucial for services such as railways, buses, banks, building societies, insurance companies, delivery services and trade services, e.g. plumbers, carpet fitters, car repair.

Responsiveness - the willingness to help customers and to provide prompt service. This dimension is particularly prevalent where customers have requests, questions, complaints and problems.

Assurance - the employees' knowledge and courtesy, and the ability of the service to inspire trust and confidence. This dimension may be of particular concern for customers of health, financial and legal services.

Empathy - the caring, individualized attention the service provides its customers. Small service companies are better placed (though not necessarily better at) 
for treating customers as individuals than their larger, invariably standardized counterparts. However, relationship marketing is designed to offer a more individualistic approach for customers of large organizations.

Tangibles - the appearance of physical facilities, equipment, personnel and communication materials. All of these are used in varying degrees to project an image that will find favor with consumers. Tangibles will be of particular significance where the customer's physical presence at a service facility is necessary for consumption to occur, e.g. hair salon, hotel, night-club.

Although SERVQUAL has been empirically tested in a number of studies involving 'pure"' service settings, its use in retail store environments has been limited. Further, improvements and measurements of quality in retailing cannot be approached in the same way as that of the services perspective. The uniqueness of the services offered by a retailer makes the uses of scales developed for other service categories somewhat questionable (Mehta, Lalwani , \& Han , 2000, p. 63). SERVQUAL dimensions do not fit all services. Every service may require a separate SERVQUAL measurement scale which relate to specific features of that sector. This can bring new dimensions to the SERVQUAL measurement (Parasuraman et.al., 1993, p. 145). Considering this aspect of the SERVQUAL literature, it can be said that, adapted version of SERVQUAL scale should be used in assessing retailers' service quality.

\section{Research Methodology}

The purpose of this study is to compare the consumer attitudes towards the SERVQUAL levels of national and local retailers. In the light of the objectives of the study, the survey population was identified as people lives in Sakarya/Turkey and aged above 18 who have shopped at both national and local retailers at least for one time.

Convenience sampling method was employed for the study. Data were collected by means of structured questionnaire. The questionnaire consists of two sections. First section required respondents to evaluate service components of both local and national markets separately. Second section contained questions pertaining to respondent demographic profile.

The data used for the study were obtained from the city of Sakarya between March-April 2016 period. Trained students directly applied the surveys to the people who have shopped at both national and local retailers at least for one time. After the elimination of the surveys which has lack of information, there were 211 surveys left convenient for further analysis.

Because SERVQUAL presents general quality dimensions for service industries, the original scale did not used for the study. The questionnaire developed based on the previous literature which was more convenient to measure retailers' service quality level (Parasuraman et.al.1993, p. 145).

Factor analyses were implemented to determine if the dimensions of retailer service quality scale has the same range for this study. Then independent sample t-test was implemented to examine the possible differences between national and local retailers with respect to service quality dimensions. SPSS 20 Statistical data analysis program was used to do necessary data analyses. study;

Four main hypotheses were tested in the study to reach the purposes of the 
H1: There is a significant difference between national and local retailers with respect to perceptions towards Physical Aspects dimension of SERVQUAL scale.

H2: There is a significant difference between national and local retailers with respect to perceptions towards Problem Solving dimension of SERVQUAL scale.

H3: There is a significant difference between national and local retailers with respect to perceptions towards Customer Interest dimension of SERVQUAL scale.

H4: There is a significant difference between national and local retailers with respect to perceptions towards Personal Interaction dimension of SERVQUAL scale.

\section{Findings}

\subsection{Demographics}

Table 1 shows demographic characteristic of the sample. According to the demographic findings of the study, there are more male than female in the sample $(54 \%$ of the population was male while $\% 44$ was female). $53 \%$ of the population was married and most of them had children (44\% of the total population). The majority of the population is in 21-30 age group and most of the people in the sample are living in a 4 people family $(32.7 \%)$. Around $80 \%$ of the sample has at least high school degree. Considering $40.4 \%$ of the sample has 1000 tl or less monthly income, it can be said that, the people in the sample are mostly in lower income group.

\section{Table 1. Demographics}

\begin{tabular}{|c|c|c|c|c|c|c|c|}
\hline & & f & $\%$ & & & f & $\%$ \\
\hline \multirow{2}{*}{ Sex } & Men & 97 & 46,0 & \multirow{2}{*}{$\begin{array}{l}\text { Marital } \\
\text { Status }\end{array}$} & Married & 111 & 52,6 \\
\hline & Woman & 114 & 54,0 & & Single & 100 & 47,4 \\
\hline \multirow{2}{*}{$\begin{array}{l}\text { Do you have } \\
\text { children? }\end{array}$} & Yes & 94 & 44,5 & \multirow{5}{*}{$\begin{array}{c}\text { How } \\
\text { many } \\
\text { people } \\
\text { do you } \\
\text { living } \\
\text { with? }\end{array}$} & 1 & 13 & 6,2 \\
\hline & No & 117 & 55,5 & & 2 & 31 & 14,7 \\
\hline \multirow{5}{*}{ Age } & 20 and less & 20 & 9,5 & & 3 & 39 & 18,5 \\
\hline & $21-30$ & 87 & 41,2 & & 4 & 69 & 32,7 \\
\hline & $31-40$ & 40 & 19,0 & & 5 and above & 59 & 28,0 \\
\hline & $41-50$ & 45 & 21,3 & \multirow{6}{*}{$\begin{array}{l}\text { Monthly } \\
\text { Income } \\
\text { Level }\end{array}$} & 1000 TL and less & 85 & 40,3 \\
\hline & 51 and above & 19 & 9,0 & & 1001-2000 TL & 56 & 26,5 \\
\hline \multirow{4}{*}{$\begin{array}{c}\text { Level of } \\
\text { Education }\end{array}$} & Primaray\&Secondary & 41 & 19,4 & & 2001-3000 TL & 38 & 18,0 \\
\hline & Highschool & 84 & 39,8 & & $3001-4000$ TL & 19 & 9,0 \\
\hline & University & 60 & 28,4 & & 4001 TL and & 13 & 60 \\
\hline & After Graduate & 26 & 12,3 & & above & & \\
\hline
\end{tabular}

The results of the reliability test of service quality scale for both local and national retailers, selling FMCG products, can be seen at table 2. For this alpha values to be above 0,70 shows that the scale is reliable (Altunış1k vd., 2012, s.124). According to the alpha results we can say that both scales are reliable (alpha value for Local Retailer SERVQUAL = 0,818, alpha value for National Retailer SERVQUAL=0,809) The result of KMO tests shows that the sufficiency of the sample is perfect for both scales (KMO for Local Retailer SERVQUAL $=0,893>0,80$ and KMO for National Retailer SERVQUAL $=0,884>0,80$ ) (Kalayc1, 2010, p. 322). The results for Bartlett's test are also significant for both two kinds of retailers. These results indicate that, the statements in the scale are consistent with each other. Thus it can be said that data is convenient for executing factor analysis. 
Table 2 . Reliability and KMO Analysis

\begin{tabular}{llc}
\hline Test Value for Local Retailers & & $\begin{array}{c}\text { Test Value for National } \\
\text { Retailers }\end{array}$ \\
\hline, 818 & Cronbach's Alpha &, 809 \\
, 893 & KMO &, 884 \\
, $000^{* *}$ & Bartlett's Test &, $000^{*}$ \\
\hline
\end{tabular}

* $\operatorname{sig}<0,01$

We formed two different kinds of questionnaires to be able to examine SERVQUAL statements for both national and local retailers. Thus, we conducted two factor analyses for each group. According to the results of the factor analysis, we obtain a 4-dimension factor range for both retailer types. Only some of the statements were different with respect to retailer type. The range is different from original SERVQUAL scale but consistent with the revised version of the SERVQUAL used for retailing. All factor loadings are higher than $\% 50$ and variance explained are equally spread between dimensions.

Table 3. Factor Analysis

\begin{tabular}{|c|c|c|c|c|c|}
\hline & \multicolumn{2}{|c|}{ Local Retailers } & \multirow{2}{*}{ Statements } & \multicolumn{2}{|c|}{ National Retailers } \\
\hline & $\begin{array}{l}\text { Variance } \\
\text { Explained }\end{array}$ & $\begin{array}{c}\text { Factor } \\
\text { Loadings }\end{array}$ & & $\begin{array}{l}\text { Variance } \\
\text { Explained }\end{array}$ & $\begin{array}{l}\text { Factor } \\
\text { Loadings }\end{array}$ \\
\hline \multirow{6}{*}{ 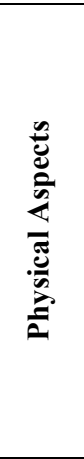 } & \multirow{6}{*}{20,734} &, 597 & $\begin{array}{l}\text { This store provides plenty of convenient } \\
\text { parking for customers. }\end{array}$ & \multirow{5}{*}{19,167} &, 737 \\
\hline & & ,701 & $\begin{array}{l}\text { Materials associated with this store's service } \\
\text { (such as shopping bags, catalogs, or } \\
\text { statements) are visually appealing. }\end{array}$ & &, 727 \\
\hline & & ,704 & This store offers high quality merchandise. & & ,722 \\
\hline & & ,665 & $\begin{array}{l}\text { This store has modern equipment (eg. Cash } \\
\text { registers, scanners, etc.) }\end{array}$ & & ,643 \\
\hline & & ,685 & $\begin{array}{l}\text { The store layout at this store makes it easy for } \\
\text { customers to find what they need. }\end{array}$ & &, 542 \\
\hline & &, 570 & $\begin{array}{l}\text { This store has clean, attractive, and convenient } \\
\text { public areas (restrooms, fitting rooms). }\end{array}$ & & $\mathbf{X}$ \\
\hline \multirow{5}{*}{ 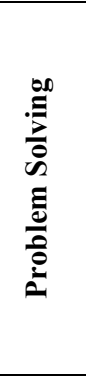 } & \multirow{5}{*}{18,496} &, 826 & $\begin{array}{l}\text { When a customer has a problem, this store } \\
\text { shows a sincere interest in solving it. }\end{array}$ & \multirow{5}{*}{18,976} &, 833 \\
\hline & &, 800 & $\begin{array}{l}\text { Employees of this store are able to handle } \\
\text { customer complaints directly and immediately. }\end{array}$ & &, 800 \\
\hline & &, 729 & $\begin{array}{l}\text { This store willingly handles returns and } \\
\text { exchanges. }\end{array}$ & &, 754 \\
\hline & & $\mathbf{X}$ & $\begin{array}{l}\text { When this store promises to do something by a } \\
\text { certain time, it will do so. }\end{array}$ & &, 515 \\
\hline & &, 586 & $\begin{array}{l}\text { Employees in this store have the knowledge to } \\
\text { answer customers' questions. }\end{array}$ & & $\mathbf{X}$ \\
\hline \multirow{2}{*}{ 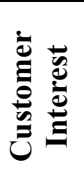 } & \multirow[b]{2}{*}{12,189} & 809 & $\begin{array}{l}\text { Employees in this store know what my needs } \\
\text { are }\end{array}$ & \multirow[b]{2}{*}{12,074} &, 815 \\
\hline & & ,698 & This store gives customers individual attention. & & 788 \\
\hline \multirow{4}{*}{ 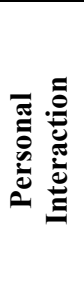 } & \multirow{4}{*}{12,954} & ,705 & $\begin{array}{l}\text { Employees in this store are available to help } \\
\text { me when needed. }\end{array}$ & \multirow{3}{*}{17,589} & ,822 \\
\hline & &, 768 & $\begin{array}{l}\text { Employees in this store are always willing to } \\
\text { help me }\end{array}$ & &, 752 \\
\hline & & $\mathbf{X}$ & $\begin{array}{l}\text { Employees in this store are never too busy to } \\
\text { respond to customers' requests. }\end{array}$ & & ,717 \\
\hline & & ,682 & $\begin{array}{l}\text { This store has operating hours convenient to all } \\
\text { their customers. }\end{array}$ & & $\mathbf{X}$ \\
\hline
\end{tabular}


After the factor analyses, we conducted Paired Sample t- Test to examine differences between SERVQUAL dimensions with respect to national and local retailers. According to results, we found significant difference between Physical Aspects and Problem Solving dimensions and retailer type $(\mathrm{p}<0,001)$. In addition, although there is a difference between Customer Interest, Personal Interaction and retailer type, the difference was found insignificant. According to these results, H1 and $\mathrm{H} 2$ supported while $\mathrm{H} 3$ and $\mathrm{H} 4$ rejected.

Table 4. Paired Sample t- Test

\begin{tabular}{|c|c|c|c|c|}
\hline Dimension & Type of Retailer & Mean & $t$ & $\mathbf{P}$ \\
\hline \multirow{2}{*}{ Physical Aspects } & Local & 3,0853 & \multirow{2}{*}{$-6,746$} & \multirow{2}{*}{, 000} \\
\hline & National & 3,5659 & & \\
\hline \multirow{2}{*}{ Personal Interaction } & Local & 3,4455 & \multirow{2}{*}{,422 } & \multirow{2}{*}{674} \\
\hline & National & 3,4139 & & \\
\hline \multirow{2}{*}{ Customer Interest } & Local & 2,7488 & \multirow{2}{*}{$-1,715$} & \multirow{2}{*}{,088 } \\
\hline & National & 2,8720 & & \\
\hline \multirow{2}{*}{ Problem Solving } & Local & 3,2607 & \multirow{2}{*}{$-2,733$} & \multirow{2}{*}{,007 } \\
\hline & National & 3,4585 & & \\
\hline
\end{tabular}

\section{Conclusions and Suggestions}

The main objective of this study was to compare two different retail types with respect to SERVQUAL scale. According to the results of the study, a significant difference found with respect to perceived SERVQUAL dimensions for different kind of retailers, similar to what Klemz et. al., (2006) and Metha et. al., (2000) found in their studies. According to the results, it can be said that, local retailers should improve their image of bad physical facilities. It is a fatal problem for them in competing national retailers. Also national retailers should improve their image about being irrelevant to the customer. Their insincere and un-emphatic image is one of the biggest problems for them to become more successful in retailing sector.

With this study, we empirically revealed the disadvantages of local retailers compare to big national retailers. But although having these disadvantages, some local retailers show great market performances in the cities they operate. Big retailers buy local retailers on a regular basis to prevent them become stronger opponents. In the future researches we strongly suggest examining the success stories of these local retailers in depth. 


\section{References}

Altunışık, R., Coşkun, R., Bayraktaroğlu, S., Yıldırım, E. (2012). Sosyal Bilimlerde Araştırma Yöntemleri Spss Uygulamalı. Sakarya: Sakarya Yayıncılık.

Baron, S., \& Harris, K. (2003). Services Marketing: Text and Cases (2nd ed.). Palgrave Macmillan.

Çelen, A., Erdogan, T., \& Taymaz, E. (2005). Fast Moving Consumer Goods: Competitive Conditions and Policies. ERC Working Paper in Economics, (June), $1-56$.

Dabholkar, P. a., Thorpe, D. I., \& Rentz, J. O. (1995). A Measure of Service Quality for Retail Stores: Scale Development and Validation. Journal of the Academy of Marketing Science, 24(1), 3-16.

Kalaycı, Ş. (2010). Spss Uygulamalı Çok Değişkenli İstatistik Teknikleri. Ankara: Asil Yayın Dağıtım.

Klemz, B. R., Boshoff, C., \& Mazibuko, N.-E. ( 2006). Emerging markets in black South African townships: Small local independently owned versus large national retailers. European Journal of Marketing, 40, 590-610.

Küçükosmanoğlu A. N., Özkeçeli A. M., Karakaya M. F. ve Yalman N.: 10th International Marketing Conference, Paris, 2011, 'Category Management vs. Discount Retailing Practices: A Case from Turkey'

Mehta, S. C., Lalwani, A. K., \& Han, S. L. (2000). Service quality in retailing: relative efficiency of alternative measurement scales for different product-service environments. International Journal of Retail \& Distribution Management, 28(2), $62-72$.

Mudie, P., \& Pirrie, A. (2006). Services marketing management. (3rd ed.) Elsevier

Parasuraman, a., Zeithaml, V. a., \& Berry, L. L. (1985). A conceptual model of service quality and its implications for future research. Journal of Marketing.

Parasuraman, A., Zeithaml, V. A., \& Berry, L. L. (1988). SERQUAL: A Multiple-Item scale for Measuring Consumer Perceptions of Service Quality. Journal of Retailing.

Rekabet Kurumu, (2011). Türkiye Hızlı Tüketim Ürünleri Perakendeciliği Sektör İncelemesi Ön Raporu

http://www.cmtevents.com/eventposts.aspx?feedid=1752\&ev=140302

http://www2.deloitte.com/content/dam/Deloitte/tr/Documents/mergers-acqisitions/trretail-sector-update.pdf 